Waste and Resource Management Volume 170 Issue WR1

Wallasea Island Wild Coast Project, UK: circular economy in the built environment

Cross ice | proceedings

\title{
Wallasea Island Wild Coast Project, UK: circular economy in the built environment
}

\author{
Martin Cross MA, MSc, MBA, PhD, CEng, MICE, CGeol, EurGeol, \\ CEnv, CSCi, SiLC \\ UK Registered Ground Engineering Adviser, Aecom, Leeds, UK \\ (martin.cross@aecom.com)
}

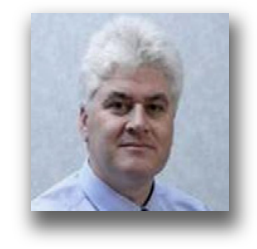

The Wallasea Island Wild Coast Project in Essex, UK, is transforming 670 ha of farmland back to coastal marshland. A total of $98 \%$ of excavated material from the Crossrail project in London has been recycled and reused, with almost half being shipped to Wallasea Island - more than $3 \mathrm{Mt}$. Up to six ships arrived daily at Wallasea, unloading $8000 \mathrm{t}$ of excavated material. A total of $\mathbf{2 4 0 0}$ shiploads of material were delivered, removing the requirement for 150000 haulage lorry movements from London's roads. The recycled excavation material has been used to raise land levels at Wallasea by $\sim \mathbf{1 . 5} \mathrm{m}$ to create Europe's largest wetland nature reserve. The project includes an innovative flood defence system incorporating new seawalls to protect vulnerable coastal areas from flooding. Partnering with nature conservation charity RSPB was a key part of Crossrail's sustainability policy. The project provides an excellent example of the circular economy in the built environment, where construction materials have been reused in a high-value conservation project providing benefits for both people and wildlife.

\section{Introduction}

For sustainable large infrastructure development, the UK civil engineering industry recognises the transition from a linear to a circular economy as a necessary focus. Today's linear 'take, make and dispose' economic model relies on large quantities of cheap, easily accessible materials and energy, and is a model that is reaching its longevity. A circular economy is an attractive and viable alternative model which the UK civil engineering industry has started to embrace (LWARB, 2015). A circular economy aims to decouple economic growth from the use of natural resources and ecosystems by using those resources more effectively through new value propositions based on durability, renewability, reuse, upgradeability, repair, sharing and dematerialisation. A circular economy is restorative and regenerative by design and aims to keep products, components and materials at their highest utility and value at all times, distinguishing between technical and biological cycles. The civil engineering industry can provide examples of projects which have harnessed the circular economy model and focused on the careful management of material flows through the design process, reverse logistics, business model innovation and cross-sector collaboration (Sugarman, 2015). The Wallasea Island Wild Coast Project in Essex, UK, exemplifies the principles underpinning the circular economy, which is moving from a system of waste to one of 'endless resourcefulness'; this more regenerative model affords a viable business opportunity to successfully tackle environmental priorities, drive performance, innovation and competitiveness while stimulating economic growth and development.

\section{Project motives}

UK's nature conservation charity RSPB proposed to undertake a national 'flagship' coastal habitat creation project on Wallasea Island located at the junction of the Crouch and Roach estuaries, Essex (Figure 1). There were several motives for, and benefits of, this project and they included socioeconomic and educational objectives. However, the two central aims were to offset historical losses of coastal habitats on this island and across the rest of Essex while also addressing the flood protection risks at Wallasea. It was also designed to act as a major contribution by the RSPB in relation to the adaptation of the coastal area to climate change. The area of Wallasea Island is considered an ideal site for such a project because it is a large area of low-lying, former intertidal land that is entirely within the coastal flood plain and where there is no pre-existing infrastructure.

The 'Wallasea Island Wild Coast Project' was planned to return the bulk of the island to a diverse range of dynamic 


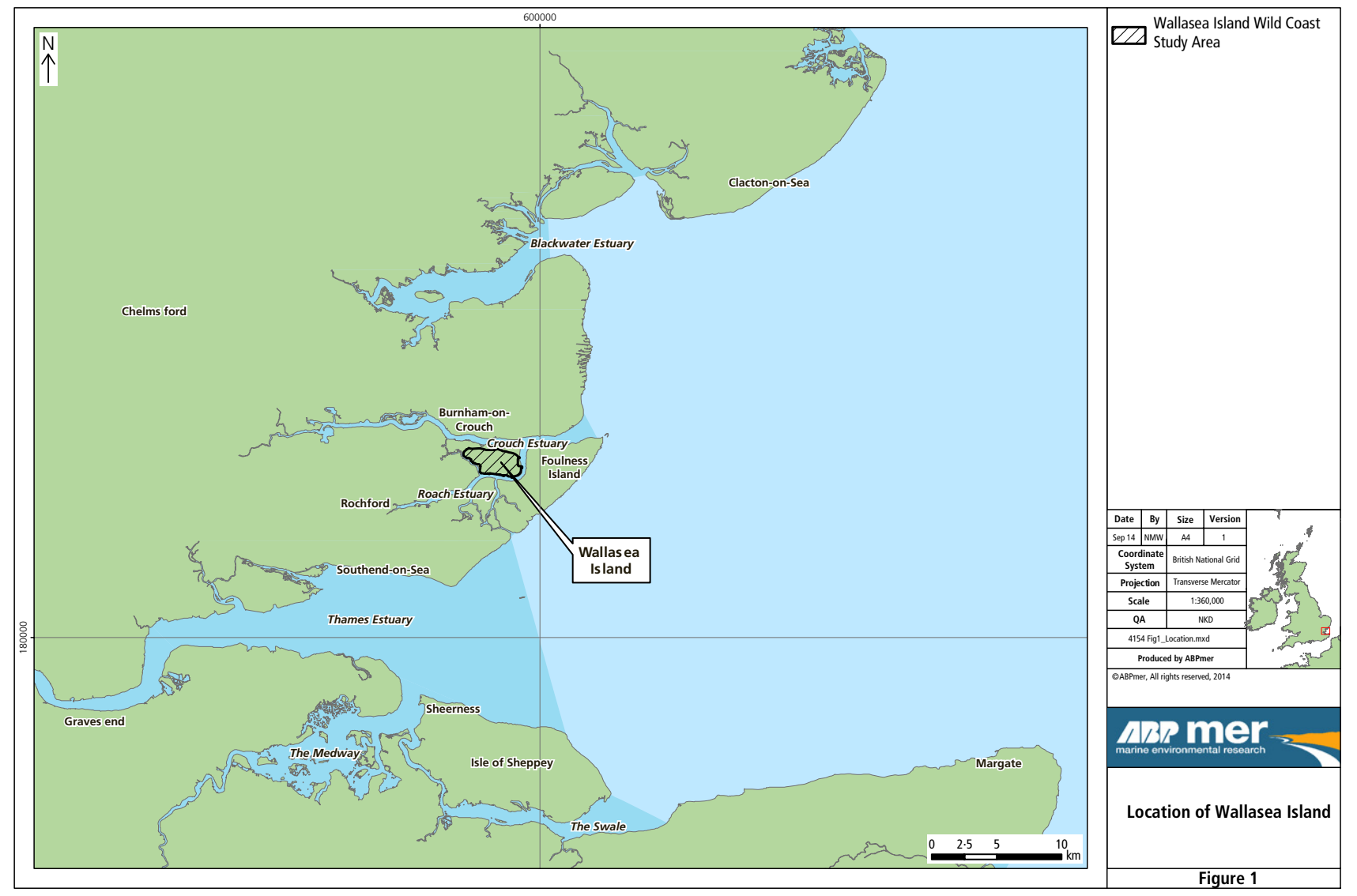

Figure 1. Location plan of Wallasea Island

intertidal habitats, with extensive transition zones, that will be rich in birds, fish and invertebrates. It is a coastal habitat restoration project on a scale that is unique in the UK. The island may have been first reclaimed from the sea by Dutch engineers' centuries ago but was finally ploughed flat 20 years ago to allow intensive wheat and rape farming (Carrington, 2012). Surrounded by tall, grassy levees, it is now $2 \mathrm{~m}$ below sea level at high tide and has a 1:5 risk of catastrophic flooding each year. The creation of new intertidal mudflat, saltmarsh and transitional habitats is designed to contribute towards the UK biodiversity action plan targets and also help mitigate for the losses of these habitats elsewhere in Essex where they are under increasing threat due to the effects of climate change and sea level rise. Rising tides are expected to destroy 1000 ha of saltmarsh in the next decade. Before the project, 30000 birds lived on Allfleet's Marsh, a small 100 ha saltmarsh at the north-eastern edge of the peninsula. The RSPB hopes the new reserve will see the return to England of lost breeding populations of spoonbills and Kentish plovers, as well as increasing already internationally important flocks of avocet, dunlin, redshank and lapwing, along with Brent geese, wigeon and curlew in winter. The RSPB expects saltwater fish such as bass, herring and flounder to use the wetland as a nursery, helping the small local seal colony and plants such as samphire, sea lavender and sea aster are expected to thrive. In addition to the habitat and nature conservation benefits, the project will increase one's understanding of the coastal environment and its management and will complement the existing Defra (2016) managed realignment site (a 115 ha scheme which was implemented on the north shore of Wallasea Island in 2006). The creation of a multifunctional nature conservation, recreational and educational facility was therefore envisaged. The RSPB was confident the project would be an inspiring example of how the impacts of climate-induced sea level rise can be managed to minimise secondary impacts, while working with estuary processes. To achieve the proposed Wallasea Island Wild Coast Project, the RSPB secured an agreement with the former landowners, Wallasea Farms Ltd, to purchase $\sim 736$ ha of mostly arable farmland on the island. The area is bounded to the north by the River Crouch, to the south-east by the River Roach and to the west by Paglesham Creek (Figure 1). 
The RSPB together with flood risk consultants ABPmer and engineering designer Aecom developed a design where 2 million $\mathrm{m}^{3}$ of water will enter and leave the site (and thus the estuary) on higher (i.e. 'spring') tides. This volume of water exchange will facilitate the creation of a wetland that replicates natural tidal cycles. The scheme was designed to improve the defensive protection of buildings located on the west of the island by the construction of a new counterwall. The counterwall was designed to help shorten the line of defence and reduce long-term seawall maintenance costs. The design of the scheme involved partitioning the total area into five 'cells' which were to be constructed in phases (Figure 2). One of the cells (cell 3) was designed to act as a flood storage area that would help to reduce flood risk across the estuary system, especially during the largest surge tides.

\section{Crossrail sustainability policy}

According to Owen Paterson, UK government environment secretary, 'It would have been enormously expensive to keep up the flood defences (of Wallasea Island); connecting the
$£ 14.8$ billion Crossrail project with the need of the RSPB to raise Wallasea Island by $2 \mathrm{~m}$ was gain, gain, gain'. He added: 'What it shows is that you should not be frightened of big infrastructure projects on environmental grounds. You can turn them to our advantage'. The new Elizabeth line railway being delivered by the Crossrail project will run $118 \mathrm{~km}$ from Reading in the west, through new twin-bore $21 \mathrm{~km}$ tunnels under central London to Shenfield and Abbey Wood in the east (Whitelaw, 2013). It will bring an additional 1.5 million people within 45 min commuting distance of London's key business districts. The project is being delivered by Crossrail Limited, a wholly owned subsidiary of Transport for London and is jointly sponsored by the Department for Transport, London. The Crossrail project adopted sustainability principles from day one of the project, taking a whole-life view of the project. This encompassed delivering a world class railway on time, safely and within available funding while minimising the amount of energy and resources used during both the construction programme and operation over its 120 year design life. In a benchmark partnership with the RSPB, Crossrail has provided more than $3 \mathrm{Mt}$ of excavated materials to construct the wetland bird

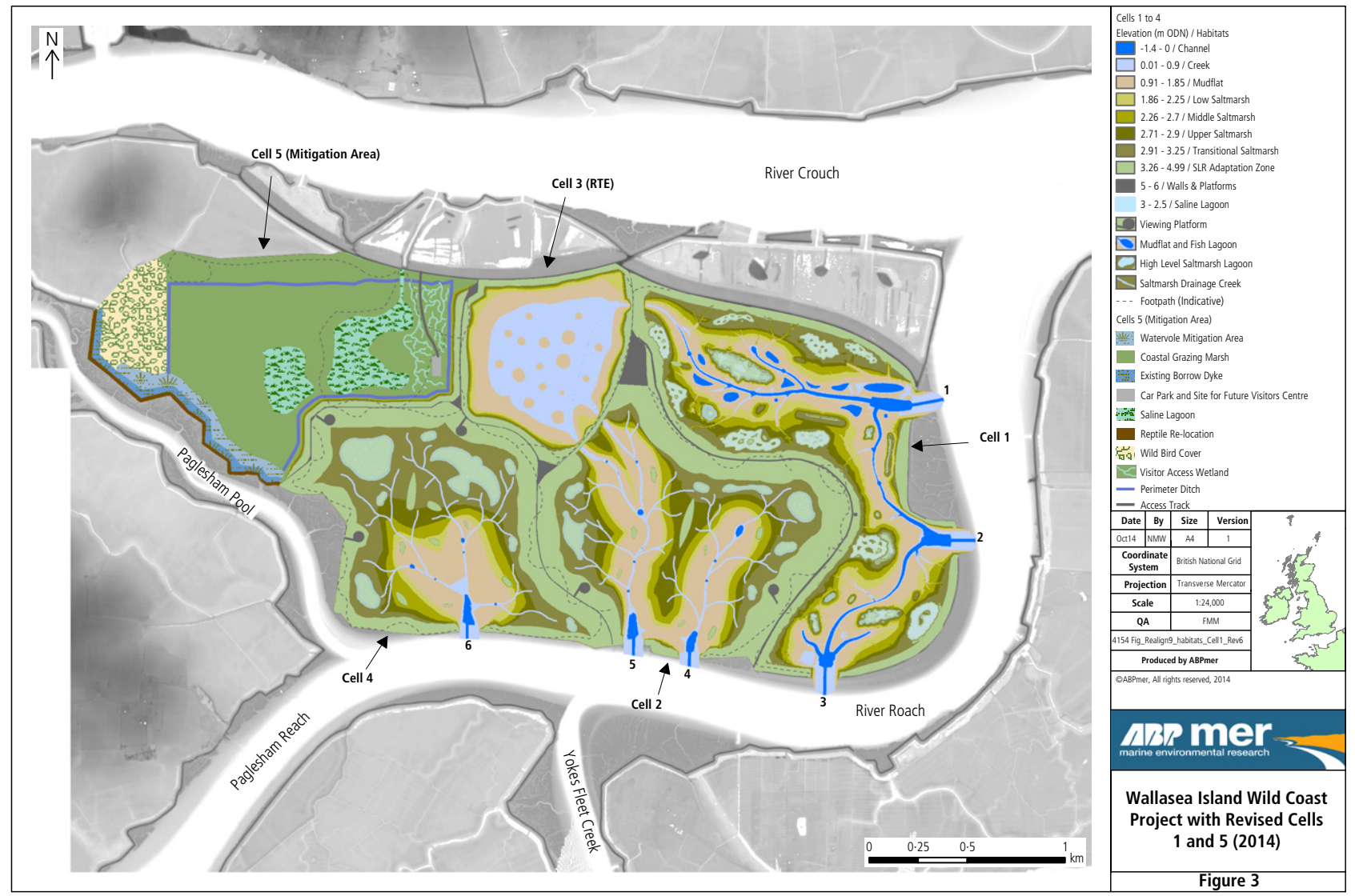

Figure 2. Partition of the scheme into five cells 
reserve at Wallasea Island (Crossrail, 2007). This negated the requirement for excavation arisings to be disposed as waste to commercial landfill sites. Eight tunnel boring machines (TBMs) were used to construct $42 \mathrm{~km}$ of tunnels on the Crossrail project. More than $7 \mathrm{Mt}$ of material was excavated by TBMs and other excavation machines during Crossrail's construction. A total of $98 \%$ of this material has been reused for nature reserves (Wallasea Island), recreational facilities (Ingrebourne Golf Course), landfill restoration (Calvert Landfill, Rainham Landfill, Ockendon Landfill and Pitsea Landfill), quarry restoration (Fairlop Quarry, East Tilbury Quarry), agriculture (Goshems Farm) and industrial land (Kingsnorth Commercial Park) in London and the south-east. Nearly $80 \%$ of the Crossrail excavation material transported to these sites was by rail and water, significantly reducing lorry journeys in central London.

\section{Crossrail recycling and reuse targets}

Recycled content by value is the standard industry metric developed by Wrap as a measure of recycled content within construction products (Wrap, 2016). Crossrail's target across the construction programme is $15 \%$, with a stretch target of $20 \%$ (Smulian, 2013). At the end of 2015, Crossrail surpassed its own target by more than double at $34 \%$, an increase of $2 \%$ from the previous year. This consistency reflects the early stage exercise undertaken by the contractors and the continuation of similar construction over the last year using similar materials, largely steel and concrete. Crossrail contractors continued to assess opportunities to procure products with higher recycled content where they exist and where there are no commercial constraints. Successes in this area included an increase in cement replacement in concrete where possible. This had the added benefit of reducing the embodied carbon in concrete. Another recycling achievement involved the use of products that met stringent performance requirements, while offering higher recycled content for the construction of internal blockwork walls. As the construction transitions to include architectural finishes, cladding and flooring, this figure is likely to change, although it remains significantly above the original $20 \%$ stretch target.

Crossrail generated $81 \mathrm{t}$ of construction and demolition material during 2014-2015 and more than $96 \%$ of this material was reused or recycled (Crossrail, 2015). In 2015, 1.5 Mt of material was excavated during the tunnelling and construction of underground stations, bringing the overall programme total to 7.3 Mt since the construction began in 2009. During 2015, $98 \%$ of the excavated material was beneficially reused to create new areas of agriculture or industrial land, nature reserves and recreational facilities.

The geology of London together with further information on the properties of geological strata is covered in Geology of
London, Memoir of the British Geological Survey (Ellison et al., 2004). The excavated material is taken from the full range of geological materials present in London (Davis and Russell, 2015), these include the following.

- Alluvium: soft clay, silt and sand.

- Fluvio-glacial deposits: sands and gravels.

- London Clay: over-consolidated silty clay.

- Lambeth Group and Harwich Formation: over-consolidated clay and water-bearing sand.

- Thanet Sands: water-bearing silty sands.

- Chalk: weak, high moisture content limestone.

The excavated material can be divided into four classes according to how the excavation method alters the in situ properties of the material. These classes are listed below from the greatest to the least induced alteration

(a) slurry TBM excavated material

(b) earth pressure balance machine excavated material

(c) material excavated from the sprayed concrete lining (SCL)

(d) material excavated from shafts, boxes and portals.

Table 1 provides a breakdown of the types of excavated material generated by the Crossrail project.

Whereas chalk slurry was produced as a result of tunnelling, this material was dried in a treatment plant to form a 'chalk cake' to allow its reuse. This chalk cake material was not sent to Wallasea Island, it was sent to Pitsea and Kingsnorth for landfill site restoration.

Before the excavated materials could be reused as fill material to construct the nature reserve, it was important that the materials were chemically screened to ensure that the material was free from potential contaminants and met agreed acceptance criteria required by the site's Environmental Permit. In line with normal waste acceptance procedures, verification

Table 1. Volumes of excavation material types generated by Crossrail

$\begin{array}{lc}\text { Type of excavated material } & \begin{array}{c}\text { Volume of material: } \\ \text { million } \mathbf{~}^{\mathbf{3}}\end{array} \\ \text { Clay } & 2.3 \\ \text { SCL } & 1.4 \\ \text { Sand and gravel } & 1.15 \\ \text { Lambeth group/Harwich formation } & 0.9 \\ \text { Piling and diaphragm walling arisings } & 0.68 \\ \text { Chalk } & 0.6 \\ \text { Demolition arisings } & 0.27 \\ \text { Total } & 7.3\end{array}$


testing was carried out on the excavation materials in three stages.

- Following excavation, but prior to dispatch to Wallasea Island.

- Visual inspection as it is unloaded.

- Periodic chemical testing at Wallasea Island.

London Clay is naturally present at Wallasea Island; the Environmental Permit allowed any similar excavated materials to be reused at Wallasea subject to verification testing. Excavated materials from Crossrail sites with more than $5 \mathrm{~m}$ clay cover required a desk study to identify any current or historic sources of pollution that might have resulted in the release of contamination. If no such sources were present, then the material was deemed suitable to be deposited at Wallasea subject to verification testing. If pollution sources were identified, then additional testing was required before it could be accepted as a suitable fill material.

At Wallasea the aquatic environment is critical; the excavated materials acceptable for reuse at Wallasea must comply with the chemical and ecological criteria specified within the Water Framework directive. The material acceptance criteria used were based on leachate testing against inert waste acceptance criteria (WAC). Detailed quantitative risk assessments were carried out on excavated materials, taking into account the environmental setting and specific receptor characteristics at Wallasea Island. Some of the excavated natural materials when tested comprised natural elements that exceeded the inert WAC limits. In such circumstances, separate hydrogeological risk assessments were carried out which set the Wallasea Island acceptance levels above the inert WAC levels. For example, leachate results for London Clay often exceed inert WAC levels for sulfate and selenium. Hydrogeological risk assessments were carried out and new WAC acceptance values were established for chloride, fluoride, molybdenum, zinc, antimony, lead, sulfate and selenium. Crossrail maintained a baseline WAC levels database of soil leachate testing results which were used to determine whether any high concentrations found were consistent with natural ground or whether they were likely to be the result of industrial contamination. If the material was confirmed as contaminated with hazardous substances, or elevated levels of non-hazardous substances of man-made origin that were above the Wallasea acceptance levels then its suitability for use at Wallasea was considered further. For sites expecting to generate arisings that included alluvium, which may include a proportion of naturally occurring organic matter, hydrocarbon results may be elevated due to natural organic substances. A suite of specialised tests and assessment procedures was used in such circumstances to distinguish between naturally derived organic compounds and man-made contaminants. Any excavated material that was considered unsuitable to be shipped to Wallasea Island was sent to an appropriately licenced landfill site.

The potential risk to the aquatic environment was a major concern to Crossrail, particularly the use of excavation materials containing grout/polymers used in the TBM tunnelling process. Injection of polymers is necessary to condition the ground, allowing a TBM to tunnel at the rate of $8-10 \mathrm{~cm} / \mathrm{min}$. A change in the polymers used for tunnelling could delay the start of the TBM, costing in the region of $£ 250000 / \mathrm{d}$ (Browne, 2015). The prevention of tunnelling waste from being deposited in close proximity to controlled waters at Wallasea Island may have resulted in significant cost implications, potentially running into millions of pounds, as well as further delays. ESG was used to determine the eco-toxic risk posed by the excavation material (checking for contaminants that could cause problems for the wetland ecosystem such as toxicity, carcinogenicity, polluting the water or stunting plant growth). Due to the intellectual property rights of the polymer manufacturers, ESG was not party to the chemical make-up of each type of polymer, which made it difficult to determine their potential environmental impacts. ESG therefore developed a methodology for analysis using a careful evaluation of polymer chemistry, utilising techniques such as inductively coupled plasma-optical emission spectroscopy and gas chromatography-flame ionisation detection (Burns, 2015). Using this methodology, ESG was able to assess the concentration of polymer within the excavated soil following biodegradation, and its potential for leaching into the surrounding environment. In addition, ESG tested the soil for asbestos, cyanide, aromatic hydrocarbons, arsenic and cadmium (Cottam, 2015).

The following additives used to facilitate excavation were considered to be inert and deemed acceptable for reuse.

- Polythene (or similar products), glass. Plastic or steel fibre and dowels used to reinforce SCL.

- Bentonite used in tunnelling or in constructing diaphragm walls.

- Concrete may make up to a proportion of the loads and may arise as: SCL, permitted if $<150 \mathrm{~mm}$ in any one dimension and lumps of concrete permitted if $<150 \mathrm{~mm}$ in any one dimension.

- Primary or recycled aggregates used in constructing diaphragm walling $<150 \mathrm{~mm}$.

The following additives required additional risk assessment to be undertaken before they could be approved for reuse.

- The use of additives such as foams, lubricants and polymers are subject to an EA permitting process based on a water risk assessment. The water risk assessment has two components: (a) an assessment of the use of additives in 
situ for risk to groundwater during tunnelling and (b) an assessment of the use of additives based on the destination and water environment/receptors at Wallasea Island.

- Where contractors are mixing additives with materials after the excavation process to better manage subsequent material handling, these additives also require a water risk assessment before they can be sent to Wallasea Island. For example, where the use of flocculants are used in drilling fluids to assist in the separation of solid arisings from liquids.

ESG completed the acceptance testing for the tunnel spoil at the western (C300), eastern (C305), Thames Tunnels (C310), Bond Street (C411, C412), Paddington (C405) and Docklands transfer station (C807) sites. The testing allowed a technically robust and meaningful assessment of the impact the polymer had on the aquatic environment. This meant that Crossrail and the Environment Agency had sufficient data and information to agree to the reuse of the material with the confidence that there would be negligible, if any, impact to aquatic life. However, it should be noted that a large volume of contaminated material was excavated from the sites at Pudding Mill Lane, Plumstead and Paddington New Yard. Although much of this material was consigned to licenced landfill sites to receive this waste, soil washing techniques were used for the New Yard material which resulted in diversion from landfill to beneficial use elsewhere. Currently, there is no published data on the volumes of excavated material that were subject to risk assessment or the various types of acceptance/verification testing.

Diversion of excavated material from landfill has been one of the key successes of the Crossrail construction programme. The partnership with the RSPB to provide acceptable fill material to construct earthworks for the Wallasea Island Wild Coast Project has been a key element of this success and an exemplar project in terms of adopting the principles of the circular economy on a large-scale infrastructure project. Crossrail either met or exceeded its targets for beneficial reuse of excavated materials against a target of $95 \%$. In addition, early partnership with the RSPB and other consultants on the Wallasea Island Wild Coast Project as part of holistic planning and collaboration enabled sustainability strategies to be implemented for the greater use of rail and water transportation to move excavation materials to the Wallasea Island site, thereby helping remove haulage lorries from London's roads.

\section{Wallasea Island earthworks scheme}

The Wallasea Island Wild Coast Project (i.e. the whole island including cells 1-5) was designed by ABPmer and Aecom for the RSPB. Phase 1 of the project (contract C807) included the completion of cell 1, parts of cell 3 and cell 5 and the tidal exchange structures. Phase 1 was funded by Crossrail, designed by Aecom and constructed by Bam Nuttall. The Bam Nuttall Van Oord Joint Venture won contract C807 with Bam Nuttall undertaking the land side works and Van Oord carrying out the marine transportation. The contract value of the phase 1 works was $£ 70$ million. Phase 1 included marine transportation and setting up the Docklands transfer station at Barking. Contract C806 (contract value $£ 12$ million) covered the construction of the off-loading facility at Wallasea; the facility was designed by Aecom and constructed by Bam Nuttall (Smith, 2011).

To achieve the coastal habitat creation, the site was divided into five cells (Figure 2) divided by internal bunds (which were aligned to follow old marsh 'island' boundaries). To allow for the development of varied saline and brackish habitats, three of the five cells were designed for full realignment and one cell was designed to be a regulated tidal exchange (RTE) area. RTE is similar to managed realignment, but rather than breaching a seawall, it included the design of water control structures such as weirs, culverts or sluice-controlled pipes within seawalls to control regular tidal inundation (RTE particularly lends itself to saline lagoon creation). Cell 5 was designed to contain mitigation habitats and visitor access facilities. Excluding structures, $\sim 133$ ha of mudflat, 276 ha of saltmarsh, 53 ha of saline lagoons, 11 ha of brackish marsh, 160 ha of grassland (including coastal grazing marsh and seawall) and 15 ha of rotational arable fields (termed 'wild bird cover') will be created. As part of phase 1, a new $2.5 \mathrm{~km}$ seawall was constructed at the western edge of a new raised area and $\sim 1 \mathrm{Mt}$ of material was obtained by excavating lagoons and features in cells 5 and 3 located to the north of the site.

Earlier to undertaking any earthworks in the cell 1 area, it was necessary to relocate certain wildlife species. Approximately 8900 reptiles (common lizards and adders), 500 fish and 380 water voles were trapped, and were transferred to a hibernaculum before earthwork operations could start. A timeline for the Wallasea wild coast project is provided in Table 2.

The project required the importation of quality-controlled inert fill materials for the construction of earthworks associated with cells 1, 2 and 4. In phase 1, the material imported by ship from Crossrail sites was used to construct cell 1 . The landscaped raising of land levels was designed so that when the tidal waters were allowed in, the volume of water would be much less $\left(2 \cdot 1\right.$ million $\left.\mathrm{m}^{3}\right)$ than in an unmanaged scenario and this would avoid adverse environmental impacts associated with the non-intervention approach. The fill included a range of inert recovered materials (including possible dredge arisings); a main material source will be the beneficial reuse of recovered tunnelled material from the Crossrail project. 
Table 2. Wallasea Island wild coast project timeline

$\begin{array}{ll}\text { Date } & \text { Process } \\ 2000 & \text { RSPB sign an option to buy } 744 \text { ha of land from Wallasea Farms } \\ 2006 & \text { Defra creates } 115 \text { ha managed realignment site along the north of Wallasea Island } \\ \text { November 2008 } & \text { RSPB announces its intention to work with Crossrail as a potential supplier of material to develop the island } \\ \text { December 2008 } & \text { A planning application is submitted to Essex County Council } \\ \text { July 2009 } & \text { Planning consent is granted following completion of a planning agreement } \\ \text { July-September 2009 } & \text { Enabling works completed, with construction of bund base for conveyor belt } \\ \text { September 2009 } & \text { Acquire first piece of land (344 ha) } \\ \text { December 2009 } & \text { Planning application for unloading facility } \\ \text { February 2010-April 2011 } & \text { Responses to planning conditions } \\ \text { September 2010 } & \text { RSPB acquires second piece of land (149 ha) } \\ \text { October-December 2010 } & \text { Design work completed for saline lagoon in cell } 5 \\ \text { February 2011 } & \text { Crossrail appoint BamNutall to construct unloading facility } \\ \text { August 2011 } & \text { BamNutall start construction of unloading facility } \\ \text { September 2011 } & \text { Complete the final phase of land purchase, giving a land holding of 744 ha } \\ \text { April 2011 } & \text { Construction of unloading facility machinery restarts } \\ \text { May 2012 } & \text { Crossrail tunnelling starts at Royal Oak } \\ \text { June 2012 } & \text { Unloading facility commissioning } \\ \text { July 2012 } & \text { First shipment of material from Crossrail tunnels arrives on Wallasea } \\ \text { August 2012 } & \text { Cell } 5 \text { saline lagoon construction scheduled to start } \\ \text { September 2012 } & \text { Cell } 3 \text { grazing marsh ground works scheduled to start } \\ \text { September 2012-June 2015 } & \text { Construction of cell } 1 \text { on the eastern part of the peninsula and construction of 2.5 km seawall at the western } \\ \text { April 2015 } & \text { edge of the new raised area of cell 1. Construction of cells } 3 \text { and } 5 \\ \text { July 2015 } & \text { Final materials from Crossrail are delivered. A total of } 3020 \text { 000 } t \text { were transported to Wallasea on 1528 ships } \\ 2025 & \text { The seawall of cell } 1 \text { was breached in three places to allow tidal flow into the marshland } \\ & \text { Further material is required to construct cells } 2 \text { and } 4 \text {. Final completion of the scheme is programmed for 2025 }\end{array}$

Crossrail considered the transportation by sea and reuse of the recovered materials for the Wallasea Island Project to be the most appropriate and sustainable solution for the use of its excavation materials. The materials used mainly composed of relict estuarine mixed sediments and marine deposits (which are eminently suitable for the creation of intertidal habitats).

To achieve the requirements for a tidal water exchange of around $2 \cdot 1$ million $\mathrm{m}^{3}$, a total of $7 \cdot 5$ million $\mathrm{m}^{3}$ of imported fill material was required for the construction of cells 1,2 and 4 . The earthworks design incorporated shallow sloping profiles throughout cells 1, 2 and 4 (the realignment cells); there was a gradual transition from the channels which guided the water into the cells which were in turn protected by internal bunds and seawalls. Internal bunds were constructed mainly with material sourced from the reprofiling of the site, as well as channel and lagoon excavation works. Six $100 \mathrm{~m}$ wide breaches were excavated through the existing seawall, and channels were excavated to their landward and seaward sides to facilitate water exchange and controlled flooding to take place. On site, a network of sinuous creeks were excavated into saltmarsh areas, and selected creeks will conduct water into 'high level' lagoons excavated from elevations associated with upper/transitional saltmarsh. Cell 3, the RTE cell, will not receive recovered material, but will be subject to reprofiling to excavate a large shallow lagoon, and create slopes up to the internal bunds. Only cell 1 was completed in phase 1 of the construction works.
A total of $3 \mathrm{Mt}$ of Crossrail excavation material and $1 \mathrm{Mt}$ of material derived from the excavation of cells 3 and 5 were used to raise the level of the cell 1 area by an average of $1.4 \mathrm{~m}$ (Cronin, 2015). A large proportion of the Crossrail material was used to construct a new seawall located at the western edge of cell 1 and designed to hold back the tide when cell 1 was breached. The seawall incorporated a basal geomembrane and was constructed in incremental stages to allow consolidation and pore-water dissipation. The seawall was constructed $4.8 \mathrm{~m}$ above the former arable farmland level, $800 \mathrm{~mm}$ higher than the required design level to account for long-term settlement. The seawall is $33 \mathrm{~m}$ wide at the base and used cohesive fill material in its construction. The new seawall was designed not to require maintenance and allow for long-term settlement.

The existing seawall was breached in three places on 11 July 2015 during a neap tide. Amphibious excavators were used to cut channels within an area of low salt mudflats located immediately outside the seawall. These ranged in length from 50 to $140 \mathrm{~m}$. Earlier to the date of the breach the former seawall was reduced from 7000 to $3000 \mathrm{~m}^{3}$ and on the day of the breach the final $3000 \mathrm{~m}^{3}$ was removed simultaneously at each of the three breaches.

One million tonnes of material used for the earthworks to construct cell 1 came from a newly excavated series of lagoons in cells 3 and 5 on the peninsula. Cell 1 was completed in July 
Waste and Resource Management Volume 170 Issue WR1
Wallasea Island Wild Coast Project, UK:

circular economy in the built

environment

Cross
2015. Cell 3 requires further imported material to complete the earthworks; this material will be placed around the perimeter, connecting the area to cells 1,2 and 4 . As part of the first phase of construction works, Aecom designed a series of inlet and outlet structures to regulate water flow between all of the different cells when they are completed. Some of the cell areas will remain dry until further breaches take place. Ultimately, further breaches are planned to the south of the peninsula to allow water into cells 2 and 4

\section{Construction methods}

A recovered inert fill management plan was developed in relation to material acceptance criteria/quality control methods to be used and how the materials were to be transported to the island. With respect to the Crossrail material, this was to be transported from London to Wallasea using ships or barges on a $24 \mathrm{~h} \mathrm{~d}$ or $7 \mathrm{~d} /$ week basis, depending on the tides (Figure 3). The material was unloaded at a purpose built unloading facility on the north shore of Wallasea, to the west of Ringwood Point (Figure 4). This was designed to accommodate two ships at any one time, as well as an appropriate amount of unloading plant. The excavation materials used for the construction of the Wallasea Island landforms composed of non-chalk material. All material imported onto the island came by way of the conveyor and was deposited by the rotary stacker in the stockpiling area. During working hours it was transferred from the rotary stacker to cell 1 by way of traditional earth moving plant (i.e. dump trucks). At maximum output, six operatives managed unloading operations. To create a stable and elevated platform which facilitated access to the unloading facility and provided a level and elevated route for the conveyor, an intertidal channel within the Defra (2016) site was temporarily infilled (footprint of 0.8 ha of the Defra (2016) site); the baseline topography was reinstated post-implementation.

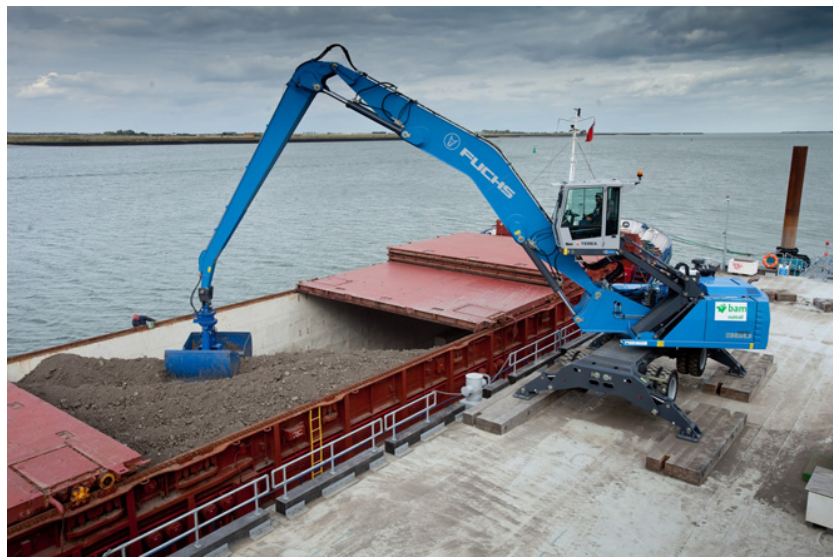

Figure 3. Loading Crossrail excavated material into a barge

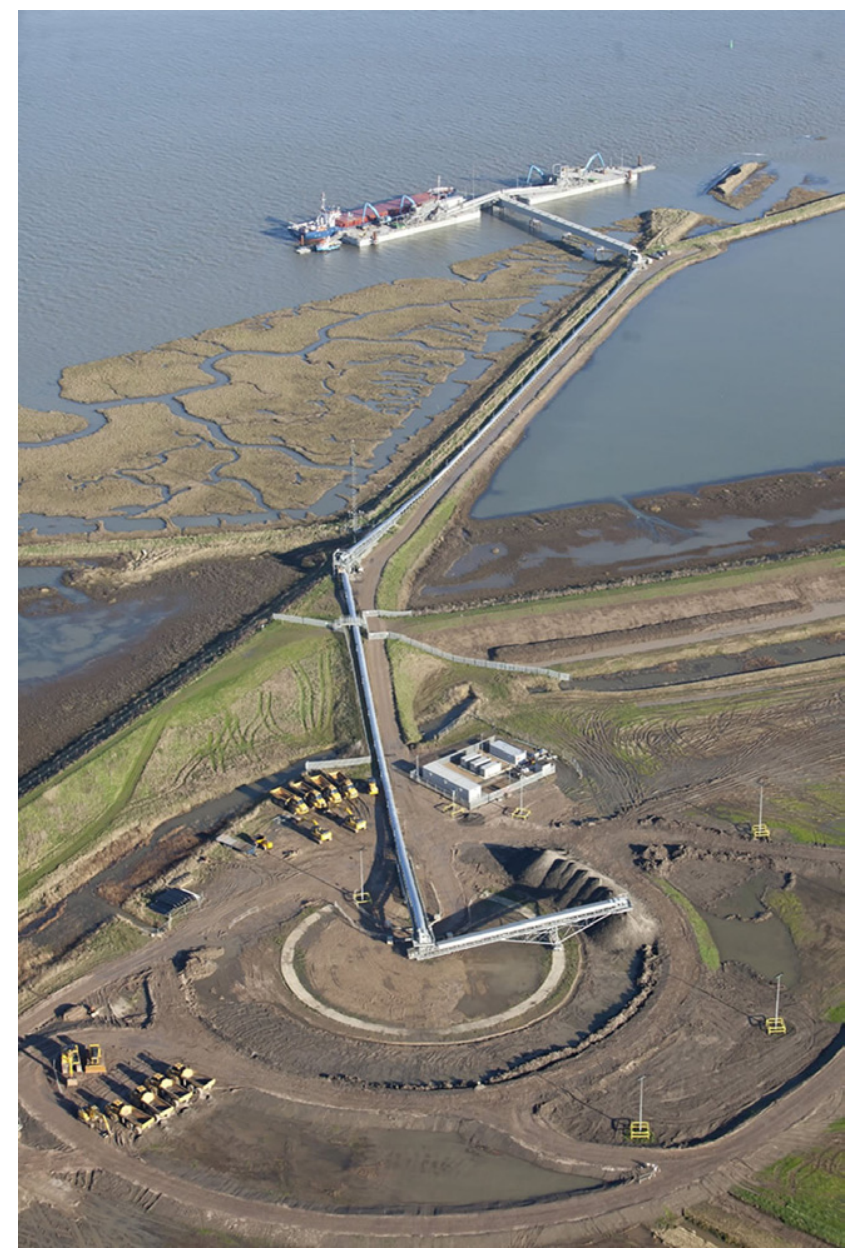

Figure 4. Unloading terminal, conveyor system and temporary storage stockpiles

With regard to on-site earthworks and landscaping, the basic site operations are described above, but with respect to the construction plant, materials were taken from the conveyors or the stockpile area and either landscaped by bulldozers or loaded to dump trucks, transported on site and landscaped by bulldozers, depending on the material type, weather and ground conditions (Figure 5). A vibratory roller was used to compact structural parts of the wetlands - for example, cell division walls. Apart from this, compaction plant was not required on any fill material that was to form the new wetland. Breaching works were subject to tidal limitations, working schedules and safety restrictions followed the methodology/safe working arrangements adopted for the Defra (2016) site breaching. The construction programme for the managed realignment was influenced by the timing of the fill material delivery from the Crossrail project and other suppliers. The project was completed in accordance with a detailed earthworks and breaching programme. As part of the phase 1 works cell 1 was 


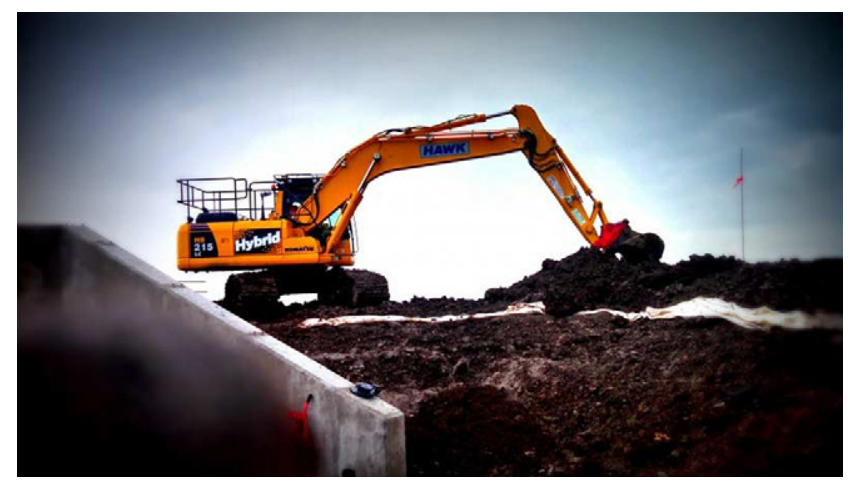

Figure 5. Earthmoving plant working on Wallasea Island

completed in 2015 (following fill delivery beginning in summer 2010), and the breaching of cell 1 took place in July 2015 (refer to Table 1) (Smith, 2015). Mitigation habitats in cell 5 will be constructed as necessary, with a small 2 ha water vole mitigation area being constructed early in the programme (with a phased annual expansion to 6 ha). These works were carried out by Bam Nuttall who was also responsible for the methods of working, site risk assessments, and site health and safety. Figure 6 shows an aerial photograph of the earthworks at Wallasea Island.

An independent technical advisory panel comprising local representatives from Natural England, the Environment Agency, the Crouch Harbour Authority, Rochford District Council and Cefas along with Wallasea Farms Ltd, the RSPB and consultants ABPmer and Aecom were responsible for overseeing the project's environmental quality and project objectives. Panel decisions were informed by a comprehensive monitoring package, the methodology of which was agreed by the panel, which included: (a) impact verification monitoring (immediately before and after breaching to confirm the findings and assumptions of the assessments; $(b)$ sediment settling and ecological functioning monitoring (on an ongoing basis during the construction and post-breach stages to verify the interrelated aspects of sediment settlement, habitat creation and ecological functionality) and (c) mitigation habitat success monitoring (post-implementation for a set period, to determine whether the created habitats within cell 5 are functioning as expected). A local liaison group was established with representatives from the local community, Essex County Council and project staff.

\section{Shipment of fill, conveyance and earthworks control}

The excavated material that has been used on the project has taken a circuitous route to Wallasea in Essex. Excavation material from the central and eastern station boxes and shafts was taken by lorry to the Docklands transfer station. Eastern and central tunnelling material was supposed to be transferred to Wallasea by way of the Limmo Peninsula; however, this material was not shipped due to its high moisture content and unsuitability for shipping. The excavation material from the western tunnels was taken by freight train to a transfer station further east at Northfleet. The first train load of the material ran from Westbourne Park in May 2012; at the peak of tunnelling, up to five freight trains were operated in a day. At these two locations material was loaded onto $2500 \mathrm{t}$ capacity freight ships and transported to a $180 \mathrm{~m}$ long jetty located on the northern side of Wallasea Island, adjacent to the River Crouch. The jetty designed by Aecom can take two $90 \mathrm{~m}$, $2500 \mathrm{t}$ ships simultaneously; the ships were unloaded onto a conveyor system which transferred excavation material $800 \mathrm{~m}$ onto the island. Only one shipment of excavation material arrived from Instone Wharf; however, this was too wet to unload and was sent back for disposal elsewhere. The majority of materials excavated from the eastern running tunnels had high moisture contents and could not be shipped to Wallasea. The marine transportation contract was awarded to a joint venture comprising Bam Nuttall and Van Oord UK Ltd. At peak, two unloading machines per pontoon serviced four ships and unloaded up to $10000 \mathrm{t}$ of material over a $24 \mathrm{~h}$ period. Excavation material has been shipped to Wallasea Island since 2012. To accommodate tidal movements up to $6 \mathrm{~m}$, the conveyor comprised a flexible section on the pontoon connecting to a fixed shore section. The stacker was fully automated to continue to load material onto a store capable of holding $16000 \mathrm{t}$ of material, even when nobody was working on site at nights and weekends. The excavation material was then transferred using 28 dump trucks to six excavators and five bulldozers working on cell 1 . The final earthworks design configuration was controlled using ground positioning satellite information.

There were some initial problems relating to the conveyance of materials due to the variable clay content of the materials arriving on freight ships from east London. The heavy tunnelled clay tended to clog the conveyor system. A series of augers were installed at various intersections along the conveyor system. In addition, excavation materials from the Barking freight vessel were mixed with excavation material from the Northfleet vessel. The material from the Barking vessel had not been excavated using TBMs; the material tended to be a drier more granular material. Mixing the excavation materials together using augers prevented material bulking problems and blockage of the conveyor system. Once the bulking problem had been resolved the efficiency of the conveyor was doubled. The first $1 \mathrm{Mt}$ of material took 62 weeks to move; however, after the conveyor had been modified with augers and use of mixed batches of excavation material the second $1 \mathrm{Mt}$ of material only took 32 weeks to move. 


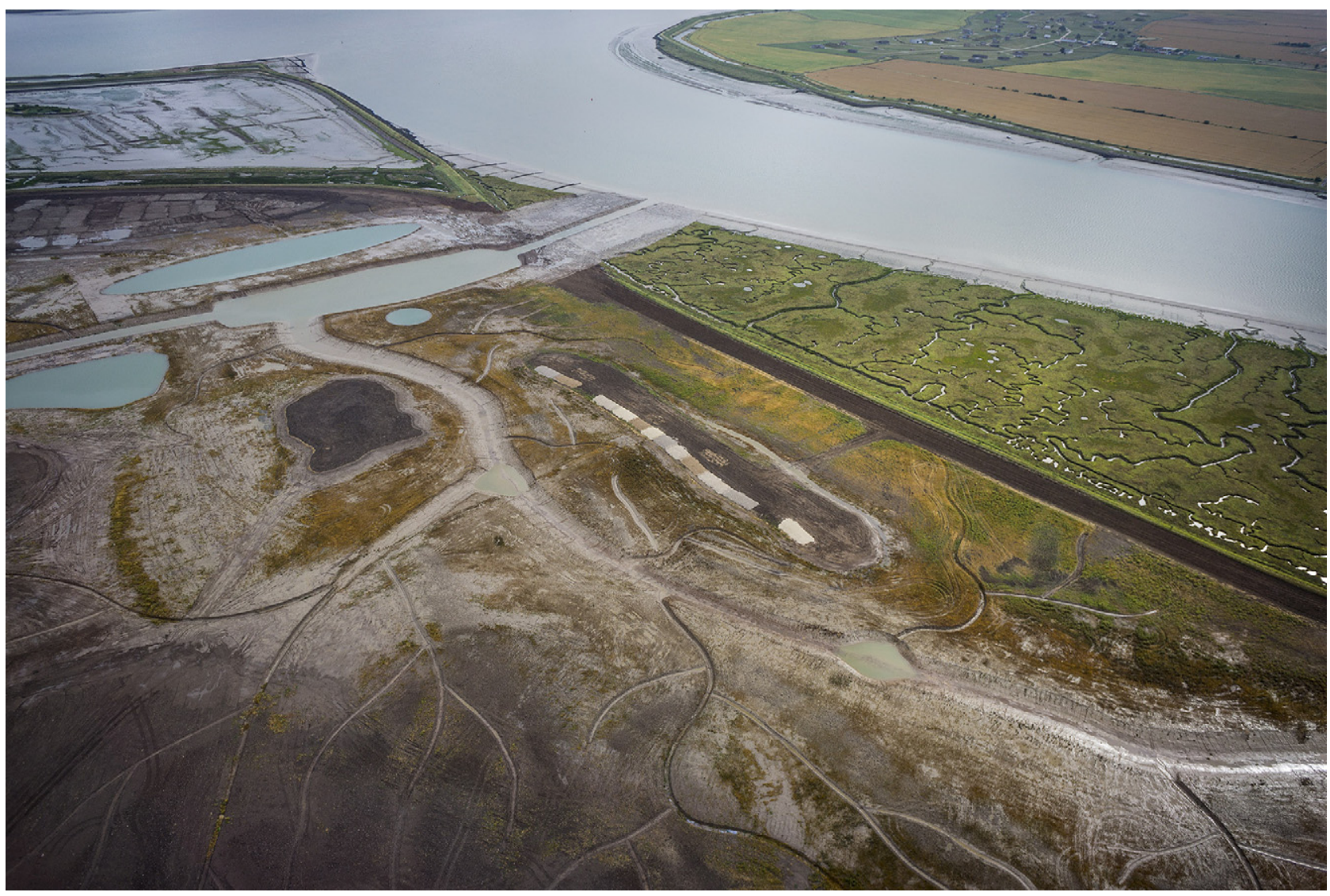

Figure 6. Aerial photograph of earthworks construction at Wallasea Island

RSPB envisaged that further in the programme, excavation material derived from projects like Crossrail 2 and Thames Tideway would be used to construct cells 2 and 4 to complete the project. However, it is now understood that RSPB are revising the design and planning permission to not import additional materials to Wallasea for the completion of cells 2 and 4 due to lack of interest by Crossrail and Thames Water. RSPB is now looking to keep cells 2 and 4 at existing levels and flood with shallow water using existing sluice structures to create shallow wetland habitats.

\section{Discussion}

The original 2014 'circular economy package' included a $70 \%$ recycling target by 2030, restrictions on incineration and landfill and high reuse objectives. The UK is currently struggling to remain on course to meet the $50 \%$ recycling target for 2020 set out in the Waste Framework Directive (European Union Directive 2008/98/EC (EC, 2008)). By the time of the next general election, it should be clearer whether that $50 \%$ represents the summit of UK ambitions, or is seen as a staging post towards a decisive break with the linear economy of the past. The European Commission has released a strategy to further extend the ambitions for a circular economy in Europe; however, Britain's referendum decision to leave the EU will create uncertainty in the UK in relation to the adoption of this strategy.

It should be noted that the Environment Agency permitted this project as a recovery activity despite the fact that the importation of excavation waste did not meet the Waste Framework Directive's definition of 'recovery' because the project would not have been undertaken if the waste material had not been available and it also did not replace the use of a non-waste material. This has been highlighted by a recent appeal judgement $R$ (Tarmac Aggregates Ltd) v. Secretary of State for Environment, Food and Rural Affairs (2016). The Environment Agency has now updated its guidance on the definition of waste (Defra, 2016). In this guidance section 3.1 states 'recovery' is any operation which has the main result of waste serving a useful purpose, by replacing non-waste materials that would otherwise have been used to fulfil a 
particular function. It is important to emphasise that this legal issue may limit future opportunities for the beneficial use of excavation waste from infrastructure projects as a recovery procedure under environmental permits.

A project like Crossrail will be judged on its legacy. How has the railway delivered sustainable change for those who must travel in and around London? How has it raised the bar in areas like construction impacts and personal safety? Has the project actually made people think differently about how to build infrastructure on this scale? Crossrail is big enough to make a difference in all these areas and the statistics suggest it is doing just that. Crossrail has been genuinely innovative in the use of lower emission, quieter machinery and equipment. It has demanded contractors to go that bit further in sourcing sustainable supplies and generally buying into the sustainability ethos of the project. Sustainability has become a factor in all decision making and has helped drive the project forward and thus created a sustainability legacy. The project was committed to a programme of external assessment through schemes such as Ceequal and Breeam, which has been adopted for all stations in the central section. The requirement for sustainability thinking at the earliest design stage of the project demanded Breeam targets to meet a 'very good' or 'excellent' rating.

Defra (2016) is funding a detailed monitoring programme to evaluate the success of the Wallasea wetlands site and determine whether it meets its targets as a compensatory habitat, and to verify whether any physical and ecological changes that occur in the adjacent Crouch and Roach estuaries are within the limits predicted.

In relation to the principles underlying the circular economy, a total of $98 \%$ of the excavated material has been recycled and reused with $50 \%$ made available to the RSPB for Wallasea Island and the remainder used for agricultural land and recreational facilities. Nearly $80 \%$ of Crossrail's excavated material has been transported by train and ship on a tonne per kilometre basis removing 150000 lorries off the streets of London.

The chief executive officers engaged on the project have fully endorsed the sustainability ethos and principles of the circular economy underpinning the Crossrail project. Mike Clarke, the RSPB's chief executive said, 'Wallasea Island is the biggest wetland creation project the RSPB has embarked upon and one of the most significant across Europe to date. As well as providing the material that makes this project possible, Crossrail has demonstrated a bold and inspired vision for the way in which industry and conservation sectors can work together for the benefit of people and wildlife'. Andrew Wolstenholme, Crossrail chief executive said, 'Crossrail is delighted to be involved in delivering this major new wetland at Wallasea. This trailblazing partnership with the RSPB is a key part of Crossrail's sustainability strategy and shows that by working together, the construction industry and environmental groups can benefit both the economy and the environment'.

The upshot of the Crossrail project is that the sustainability legacy is already starting to attract the attention of other major infrastructure teams, both in the UK and overseas. The Crossrail legacy may well help these projects in their efforts to embrace circular economy principles and to win a wider approval. The project can certainly be used as a benchmark for other large-scale infrastructure projects in terms of incorporating sustainable development/circular economy initiatives.

On the basis of the original design, the RSPB will require a further 7-8 Mt of material to complete the Wallasea Island nature reserve by 2025 and is currently looking for partners to provide the material. It is now understood that the RSPB are now revising the design and planning permission to complete cells 2 and 4 without the further requirement to import excavated fill material because no partners have been forthcoming in providing the volumes of fill required. The RSPB are now planning to keep cells 2 and 4 at existing levels and flood with shallow water using existing sluice structures to create shallow wetland habitats. It would appear that the potential partners such as Crossrail and Thames Water are currently looking at other options for the disposal of excavation materials.

\section{Recommendations for further research}

This paper provides a brief overview of some of the key aspects of the sustainability principles underpinning the Wallasea Island project. On reflection the author recognises that further research is required in relation to the broader implications of sustainable management of excavated soil and rock, particularly relating to large-scale infrastructure projects. It would appear that a resource perspective on excavated soil and rock in major urban conurbations in the UK is deficient. Further research on the application of a resource perspective to describe the flow of excavated soil and rock in UK urban regions, particularly London, is required. Few studies have been carried out on the potential carbon dioxide per tonne saving on large infrastructure projects for reusing excavated soil and rock and more research is required to clarify the environmental and economic benefits. The regional management of construction materials and excavated soil and rock could benefit from better coordination of construction projects. This will need strategic planning at an early stage where the future demand and availability of construction material is assessed. Decisions on all levels will be needed, from the construction project level for increasing reuse on site to the regional authority level for improving the conditions for reuse, 
such as the establishment of hubs where material can be stored and sorted for later use in construction. The effective planning of large tunnel construction projects must consider the tunnel excavation material handling (TEMH); further research is required on materials management systems and applications capable of managing the uncertainties affecting the TEMH. For example, the transportation concept of the excavated material (conveyor system, haulage lorries etc.), the storage capacity of the immediate or final repository and the processing facilities of the aggregate plant can be investigated. Excavation material derived from large-scale construction and tunnelling projects should be considered as a valuable resource; if it is managed and treated correctly, it can be used for different purposes. Further research is required on evaluating the effects of various treatments on different types of excavated rocks and soils resulting from a range of excavation methods including TBMs. In addition, further research on best practice for the application of soil and groundwater environmental risk assessment and material acceptance and verification testing associated with the reuse of large volumes of excavated materials which meets relevant environmental legislation is required.

\section{Acknowledgements}

The author acknowledges the provision of photographs and figures for this paper from RSPB, Crossrail, Bam Nuttall and ABPmer.

\section{REFERENCES}

Browne S (2015) Strictly for the birds! Rail, 4 March.

Burns D (2015) Wallasea Island - infrastructure working on behalf of conversation. Infrastructure Intelligence, 13 May.

Carrington D (2012) Crossrail earth to help create biggest man-made nature reserve in Europe. The Guardian, 17 September.

Cottam N (2015) The Crossrail legacy. Infrastructure Intelligence, 4 February.
Cronin B (2015) Island life: Crossrail Wallasea Wild Coast project. New Civil Engineer, 24 July.

Crossrail (2007) D3 - Excavated Material and Waste Management Strategy. Crossrail, London, UK, Crossrail Information Paper, Version 2-20/11/07.

Crossrail (2015) Crossrail Sustainability Report 2015. Crossrail, London, UK, EA452/LM/15.

Davis J and Russell L (2015) The Transport and Beneficial Re-Use of Crossrail Excavated Material. Crossrail Learning Legacy, Technical Paper, Crossrail, London, UK. See http://lerninglegacy. crossrail.co.uk/documents/the-transport-and-beneficial-re-use-ofcrossrail-excavated-material/ (accessed 21/10/2016).

Defra (Department for Environment, Food and Rural Affairs) (2016) See http://www.gov.uk/government/publications/legal-definitionof-waste-guidance (accessed 20/04/2016).

EC (European Community) (2008) The Waste Framework Directive. Directive 2008/98/EC of the European Parliament and of the Council on waste. Off. J. Eur. Commun. L312/3, Art 14

Ellison RA, Woods MA, Allen DJ et al. (2004) Geology of London. British Geological Survey, Keyworth, UK.

LWARB (London Waste \& Recycling Board) (2015) London the Circular Economy Capital: Towards a Circular Economy - Context and Opportunities. London Waste and Recycling Board, London, UK.

$R$ (Tarmac Aggregates Ltd) v. Secretary of State for Environment, Food and Rural Affairs [2016] Env. L.R. 15 [2015] EWCA Civ 1149, C1/2015/2871, [2015] WLR(D)473.

Smith C (2011) Crossrail readies Wallasea to receive waste. Ground Engineering, 6 October.

Smith C (2015) Last Crossrail spoil dispatched to Wallasea. Ground Engineering, 23 April.

Smulian M (2013) Birds help Crossrail hit recycling target. Materials Recycling World, 18 February.

Sugarman M (2015) Can we build a circular economy by 2050? Waste experts discuss how London can prepare for the future of resource management. Institution of Civil Engineers, Home News, 18 November

Whitelaw J (2013) Crossrail: Tunnelling on an epic scale. INGENIA September: pp. 15-21.

Wrap (Waste and Resources Action Programme) (2016) Setting a Requirement for Recycled Content in Building Projects. Wrap, UK. See http://www.wrap.org.uk/sites/files/wrap/procurement Guidance 204pp2.pdf (accessed 20/04/2016).

\section{How can you contribute?}

To discuss this paper, please email up to 500 words to the editor at journals@ice.org.uk. Your contribution will be forwarded to the author(s) for a reply and, if considered appropriate by the editorial board, it will be published as discussion in a future issue of the journal.

Proceedings journals rely entirely on contributions from the civil engineering profession (and allied disciplines). Information about how to submit your paper online is available at www.icevirtuallibrary.com/page/authors, where you will also find detailed author guidelines. 